\title{
HUBUNGAN KONSUMSI SAYUR DAN BUAH DENGAN STATUS GIZI PADA REMAJA DI SMP KABUPATEN PESISIR SELATAN
}

\author{
Putri Aulia Arza ${ }^{1)}$, Liza Nola Sari ${ }^{2)}$ \\ ${ }^{1}$ Prodi Gizi, Fakultas Kesehatan Masyarakat, Universitas Andalas \\ SMPN 2 BAYANG, Kabupaten Pesisir Selatan, Sumatra Barat \\ e-maili: putriauliaarza@ph.unand.ac.id
}

\begin{abstract}
ABSTRAK
Asupan nutrisi merupakan hal yang perlu diperhatikan pada masa remaja awal. Hal ini dikarenakan pada masa remaja merupakan permulaan percepatan pertumbuhan manusia yang berdampak terhadap status gizi kedepannya. Tujuan penelitian ini untuk mengetahui hubungan konsumsi sayur dan buah dengan status gizi pada remaja di SMP Kabupaten Pesisir Selatan. Metode penelitian yaitu diskriptif korelasi dengan jumlah sampel 67 siswa di SMP Kabupaten Pesisir Selatan, teknik pengambilan sampel menggunakan quota sampling. Instrumen yang digunakan berupa lembar kuesioner konsumsi sayur dan buah serta status gizi remaja. Analisis menggunakan uji chi square. Hasil penelitian menunjukkan bahwa ada hubungan konsumsi sayur dengan status gizi remaja dengan hasil $\mathrm{p}=0,01$, ada hubungan konsumsi buah dengan status gizi remaja dengan hasil $\mathrm{p}=0,0001$. Kesimpulan penelitian bahwa ada hubungan antara konsumsi buah dan sayur dengan status gizi remaja di SMP Kabupaten Pesisir Selatan. Dari hasil penelitian ini disarankan perlu adanya edukasi gizi kepada remaja untuk meningkatkan kesadaran konsumsi buah dan sayur karena mempunyai pengaruh terhadap status gizi pada remaja.
\end{abstract}

Kata kunci: konsumsi buah dan sayur, remaja, status gizi

\section{ABSTRACT}

Nutritional intake is something that needs to be considered in early adolescence. This is because adolescence is the beginning of the acceleration of human growth which has an impact on future nutritional status. The purpose of this study was to determine the relationship between consumption of vegetables and fruits with nutritional status in adolescents at Pesisir Selatan District Junior High School. The research method is descriptive correlation with a sample of 67 students in Pesisir Selatan Regency Junior High School, the sampling technique uses quota sampling. The instrument used was a questionnaire sheet on the consumption of vegetables and fruit and the nutritional status of adolescents. Analysis using chi square test. The results showed that there was a relationship between vegetable consumption and adolescent nutritional status with $p=$ 0.01 , there was a relationship between fruit consumption and adolescent nutritional status with $p=0.0001$. The conclusion of the study is that there is a relationship between consumption of fruits and vegetables and the nutritional status of adolescents in Pesisir Selatan District Junior High School. From the results of this study, it is suggested that there is a need for nutritional education to adolescents to increase awareness of fruit and vegetable consumption because they have an influence on nutritional status in adolescents.

Keywords: consumption of fruit and vegetables, adolescents, nutritional status

\section{PENDAHULUAN}

Periode remaja merupakan periode transisi antara anak-anak dan dewasa.
Periode ini berarti sebagai periode permulaan percepatan pertumbuhan manusia. Baik itu 
pertumbuhan yang dapat tampak secara kasat mata seperti pertumbuhan tinggi dan pertambahan massa tubuh berupa berat badan, maupun pematangan organ tubuh yang terdapat di dalam tubuh itu sendiri.. Remaja rentan mengalami masalah gizi karena merupakan masa peralihan dari masa anak-anak ke masa dewasa yang ditandai dengan perubahan fisik fisiologis dan psikososial. Disamping itu kelompok ini berada pada fase pertumbuhan yang pesat (Growth Spurt) sehingga dibutuhkan zat gizi yang relative lebih besar jumlahnya.

Gizi pada masa remaja penting untuk diperhatikan, Masa remaja merupakan perubahan dari masa kanak-kanak menuju dewasa. Masa ini terjadi perubahan secara fisik, mental maupun sosial. Hal tersebut menyebabkan permasalahan yang sering terjadi dikalangan remaja putri adalah kurang gizi dan pola makan yang salah (Arisman, 2009).

Dengan memahami bahwa tubuh remaja terus tumbuh dengan laju cepat, sangat penting untuk mereka mendapatkan makanan dengan kualitas yang bagus dan tepat untuk memenuhi kebutuhan energi dan nutrisi lainnya, terutama zat pembangun seperti lemak dan protein (Putri, 2021).

Untuk memenuhi kebutuhan gizinya, remaja harus mendapatkan asupan makan bergizi dan seimbang sesuai Angka Kecukupan Gizi (AKG) yang ditetapkan. Pola makan remaja akan menentukan jumlah zat-zat gizi yang diperlukan oleh remaja untuk pertumbuhan dan perkembangannya. Jumlah makanan yang cukup sesuai dengan kebutuhan akan menyediakan zat-zat gizi yang cukup pula bagi remaja guna menjalankan kegiatan fisik yang sangat meningkat. Pada kondisi normal diharuskan untuk makan 3 kali dalam sehari dan keseimbangan zat gizi diperoleh apabila hidangan seharihari terdiri dari 3 kelompok bahan makanan (Mourbas, 2001).
Kekurangan zat gizi pada masa remaja dapat menghambat pertumbuhan dan kematangan remaja. Hal ini termasuk pertumbuhan fisik, mental hingga seksual. Dampak dari kekurangam gizi ketika remaja juga memungkinkan merupakan proses akumulasi dari kondisi malnutrisi pada bayi dan masa kanak-kanak. Oleh karena itu, dampak dari malnutrisi dapat terlihat pada periode usia yang sama dan juga memungkinkan terlihat pada periode perkembangan tubuh berikutnya di waktu yang lama. (WHO, 2005).

UNICEF, WHO dan World Bank dalam Joint Child Malnutrition Estimates, 2020, menyebutkan bahwa Stunting merupakan kondisi buruk yang terjadi akibat kekurangan nutrisi kronis pada masa awal kehidupan anak-anak. Setidaknya terdapat 144 juta anak-anak balita di seluruh dunia menderita Stunting. Kejadian Stunting banyak ditemukan pada anak dan remaja pada populasi yang kekurangan gizi.

Berdasarkan data Riskedas 2018, pada remaja umur 1315 tahun sekitar 1/3 remaja mempunyai tubuh pendek dan sangat pendek. Prevalensi pendek pada usia tersebut adalah 18,5\% dan sangat pendek sebesar 7,2\%. Data prevalensi pendek dan sangat pendek di Provinsi Sumatera Barat sendiri relatif sama dengan data tingkat nasional yaitu pada angka $18,4 \%$ dan $7,2 \%$ secara berurutan.

Berdasarkan data Riskesdas 2018, remaja usia 13-15 tahun menderita kurus sebanyak 6,8\% dan sangat kurus sebesar 1,9\%. Data ini tidak terlalu jauh berbeda dengan data di Provinsi Sumatera Barat di mana prevalensi kurus sebesar 6,0 \% dan sangat kurus 2,1 
$\%$. Kekurangan konsumsi sayur dan buah menyebabkan tubuh kekurangan gizi seperti vitamin, mineral, serat dan tidak seimbangnya asam basa tubuh, sehingga dapat mengakibatkan timbulnya berbagai penyakit.

Tujuan penelitian untuk mengetahui hubungan kebiasaan konsumsi sayur dan buah dengan status gizi remaja SMP di Kabupaten Pesisir Selatan

\section{METODE PENELITIAN}

Jenis penelitian adalah deskriptif korelasi dengan pendekatan cross sectional. Populasi adalah siswa SMP di Kabupaten Pesisir Selatan. Pengambilan sampel dalam penelitian ini menggunakan teknik quota sampling berjumlah 67 siswa. Siswa mengisi kuesioner tentang kebiasaan konsumsi sayur dan buah,

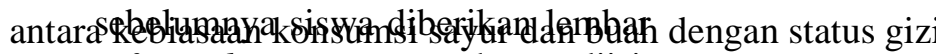
informed consent yang harus diisi. Peneliti mendampingi siswa dalam mengisi kuesioner. Penelitian dilaksanakan dimulai pada bulan Maret - Juni 2020. Analisis data menggunakan chi square.

\section{HASIL DAN PEMBAHASAN}

a. Gambaran Status Gizi pada Remaja di SMP Kabupaten Pesisir Selatan

Tabel 1. Distribusi Frekuensi Status

Gizi Remaja di SMP Kabupaten Pesisir Selatan $(n=67)$

\begin{tabular}{lcc}
\hline \multicolumn{1}{c}{ Status Gizi } & N & $\%$ \\
\hline Kurus & 29 & 43 \\
Normal & 32 & 48 \\
Gemuk & 3 & 4 \\
Obesitas & 3 & 4 \\
Total & 67 & 100 \\
\hline
\end{tabular}

Berdasarkan Tabel 1 menunjukkan bahwa jumlah remaja di SMP Kabupaten Pesisir Selatan dengan status gizi normal 32 siswa (48\%), kurus 29 siswa (43\%) serta gemuk dan obesitas sama yaitu 3 siswa (4\%). Mayoritas status gizi remaja di
SMP Kabupaten Pesisir Selatan adalah normal dari total 67 siswa.

b. Gambaran Konsumsi Sayur dan Buah pada Remaja di SMP Kabupaten Pesisir Selatan

Tabel 2. Distribusi Frekuensi Konsumsi Sayur pada Remaja di SMP Kabupaten Pesisir

\begin{tabular}{|c|c|c|}
\hline \multicolumn{3}{|c|}{ Selatan $(n=67)$} \\
\hline Konsumsi Sayur & $\mathrm{n}$ & $\%$ \\
\hline Sering & 41 & 61 \\
\hline Jarang & 26 & 39 \\
\hline Total & 67 & 100 \\
\hline
\end{tabular}

Berdasarkan Tabel 2 menunjukkan bahwa konsumsi sayur pada remaja di SMP Kabupaten Pesisir Selatan dari total 67 siswa, yaitu sejumlah 41 siswa $(61 \%)$ kategori sering, 26 siswa (39\%) kategori jarang konsumsi sayur (1 kali dalam sebulan). Mayoritas remaja di SMP Kabupaten Pesisir Selatan adalah sering konsumsi sayur yaitu 1 kali dalam sebulan.

Tabel 3. Distribusi Frekuensi Konsumsi Buah pada Remaja di SMP Kabupaten Pesisir Selatan $(n=67)$

\begin{tabular}{lccc}
\hline & Konsumsi Sayur & $\mathrm{n}$ & $\%$ \\
\hline Sering & 59 & 88 \\
Jarang & 8 & 12
\end{tabular}


Berdasarkan Tabel 3 menunjukkan bahwa konsumsi buah pada remaja di SMP Kabupaten Pesisir Selatan dari total 67 siswa, yaitu 59 siswa (88\%) kategori sering dan 8 siswa (12\%) kategori jarang konsumsi buah. Mayoritas remaja di SMP Kabupaten Pesisir Selatan adalah sering konsumsi buah.

Kebiasaan siswa konsumsi buah lebih besar dibandingkan konsumsi sayur, hal ini sesuai dengan penelitian Muthmainnah dkk (2018) yaitu dari total 72 siswa sejumlah 57 siswa konsumsi < 60 gram sayur per hari. Sedangkan 57 siswa $(79,2 \%)$ konsumsi buah $>100$ gram per hari. Selain itu, penelitian Anggraeni \& Sudiarti (2018) di SMP Negeri 98 Jakarta menunjukkan rata-rata konsumsi buah dan sayur sebesar $85,13 \pm 26,58$ gram/hari.

Penelitian Hermina dan Prihatini (2016) menunjukkan bahwa konsumsi buah dan sayur penduduk Indonesia usia 13-18 tahun sebanyak $\quad 108,8$ gram/orang/hari. Hal ini sejalan dengan

c. Hubungan Konsumsi Sayur dengan Status Gizi pada Remaja di SMP Kabupaten Pesisir Selatan beberapa hasil penelitian, dimana hanya $57,5 \%$ siswa di SMP Negeri 8 Depok yang memenuhi konsumsi buah dan sayur 400 gram per hari, sementara pada $68,9 \%$ siswa di SMP Negeri 226 Jakarta Selatan dan $82,4 \%$ siswa kelas VIII dan IX di SMP Negeri 127 Jakarta Barat konsumsi buah dan sayur dalam kategori kurang (Farisa, 2012; Lestari, 2012; Nurlidyawati, 2015).

Rekomendasi Badan Kesehatan Dunia (WHO)(2013) yang terdapat dalam Pedoman Gizi Seimbang (PGS) menganjurkan konsumsi sayur dan buah-buahan sejumlah 400 gram per orang per hari, yang terdiri dari 250 gram sayur (setara $2 \frac{1}{2}$ porsi atau $2 \frac{1}{2}$ gelas sayur setelah dimasak dan ditiriskan) dan 150 gram buah (setara dengan 3 buah pisang ambon ukuran sedang atau $1 \frac{1}{2}$ potong pepaya ukuran sedang atau 3 buah jeruk ukuran sedang). Sekitar dua-pertiga dari jumlah anjuran konsumsi sayuran dan buah-buahan tersebut adalah porsi sayur.

Tabel 4. Hubungan Konsumsi Sayur dengan Status Gizi pada Remaja di SMP Kabupaten Pesisir Selatan $(n=67)$

\begin{tabular}{lccccccc}
\hline Konsumsi sayur & \multicolumn{9}{c}{ Status Gizi } & \multicolumn{2}{c}{ Total } & \multirow{2}{*}{ p } \\
& \multicolumn{2}{c}{ Normal } & \multicolumn{2}{c}{ Tidak normal } & & \\
\cline { 2 - 7 } & $\mathrm{n}$ & $\%$ & $\mathrm{n}$ & $\%$ & $\mathrm{n}$ & $\%$ & \\
\hline Sering & 22 & 53,7 & 19 & 46,3 & 41 & 100 & \\
Jarang & 10 & 38,4 & 16 & 61,6 & 26 & 100 & \\
Total & 32 & 48 & 35 & 52 & 67 & 100 & \\
\hline
\end{tabular}

Berdasarkan tabel 4 menunjukkan bahwa remaja yang sering konsumsi sayur memiliki status gizi normal sebanyak 22 siswa $(53,7 \%)$ dan tidak normal sebanyak 19 siswa $(46,3 \%)$. Sebaliknya remaja yang jarang konsumsi sayur memiliki status gizi normal sebanyak 10 siswa $(38,4 \%)$ dan tidak normal sebanyak 16 siswa (61,6\%). Dari hasil analisis statistik uji chi square didapatkan $p$ value 0,01, maka dapat disimpulkan bahwa terdapat hubungan antara kebiasaan konsumsi sayur dengan status gizi siswa. 
Hasil ini sesuai dengan penelitian Ranti, dkk (2018) yaitu terdapat hubungan antara kebiasaan konsumsi sayur dan buah dengan status gizi. Konsumsi sayur dan buah diperlukan tubuh sebagai sumber vitamin, mineral dan serat dalam mencapai pola makan sehat sesuai anjuran pedoman gizi seimbang untuk kesehatan yang optimal (Kemenkes, 2013).
Konsumsi sayur dan buah bisa mengontrol berat badan karena sayur dan buah megandung serat dan merupakan sumber antioksidan dan fitokimia dan jika dikonsumsi memiliki kalori rendah (Burhan, 2013).

d. Hubungan Konsumsi Buah dengan Status Gizi pada Remaja di SMP Kabupaten Pesisir Selatan

Tabel 5. Hubungan Konsumsi Buah dengan Status Gizi pada Remaja di SMP Kabupaten Pesisir Selatan $(\mathrm{n}=67)$

\begin{tabular}{lccccccc}
\hline Konsumsi buah & \multicolumn{9}{c}{ Status Gizi } & \multicolumn{2}{c}{ Total } & \multirow{2}{*}{ p } \\
& \multicolumn{2}{c}{ Normal } & \multicolumn{2}{c}{ Tidak normal } & & \\
\cline { 2 - 7 } & $\mathrm{n}$ & $\%$ & $\mathrm{n}$ & $\%$ & $\mathrm{n}$ & $\%$ & \\
\hline Sering & 31 & 52,5 & 28 & 47,5 & 59 & 100 & 0,0001 \\
Jarang & 1 & 12,5 & 7 & 87,5 & 8 & 100 & \\
Total & 32 & 48 & 35 & 52 & 67 & 100 & \\
\hline
\end{tabular}

Berdasarkan tabel 5 menunjukkan bahwa remaja yang sering konsumsi buah memiliki status gizi normal sebanyak 31 siswa $(52,5 \%)$ dan tidak normal sebanyak 28 siswa $(47,5 \%)$. Sebaliknya remaja yang jarang konsumsi buah memiliki status gizi normal sebanyak 1 siswa $(12,5 \%)$ dan tidak normal sebanyak 7 siswa $(87,5 \%)$. Dari hasil analisis statistik uji chi square didapatkan $p$ value 0,0001 , maka dapat disimpulkan bahwa terdapat hubungan antara kebiasaan konsumsi buah dengan status gizi siswa.

Hasil penelitian ini sesuai dengan penelitian Suryani dkk (2017), yaitu terdapat hubungan antara konsumsi buah dan sayur dengan status gizi anak sekolah. Sayur dan buah merupakan kelompok pangan dalam penggolongan FAO, yang dikenal dengan Desirable Dietary Patern atau Pola Pangan Harapan (PPH). Kelompok bahan pangan tersebut mempunyai fungsi sebagai sumber vitamin dan mineral, sehingga apabila kekurangan bahan pangan tersebut mempunyai pengaruh negatif terhadap status gizi. Oleh karena itu, konsumsi sayur-sayuran dan buah-buahan bersama-sama dengan kelompok pangan lainnya, selain berpengaruh terhadap kejadian obesitas juga dapat berpengaruh terhadap kondisi kesehatan pada umumnya (Karyawati, 2016).

\section{KESIMPULAN}

Terdapat hubungan yang signifikan konsumsi sayur dan buah terhadap status gizi pada remaja di SMP Kabupaten Pesisir Selatan.

\section{SARAN}

Perlu adanya edukasi gizi kepada remaja untuk meningkatkan pengetahuan dan mengubah kebiasaan pola konsumsi buah dan sayur karena mempunyai dampak terhadap status gizi pada remaja.

\section{UCAPAN TERIMA KASIH}

Terima kasih kepada Fakultas Kesehatan Masyarakat Universitas Andalas yang membantu dalam penyandang dana penelitian melalui hibah DIPA FKM Tahun 2020.

\section{REFERENSI}

Anggraeni Nur A, Sudiarti T. Faktor Dominan Konsumsi Sayur dan buah pada Remaja di SMPN 98 Jakarta. Indonesian Journal of Human Nutrition. 2018:5(1):1832.22.

Arisman. Buku Ajaran Ilmu Gizi: Gizi Dalam Daur Kehidupan.Jakarta : ECG; 2009

Burhan, F. Z, Sirajuddin, S. dan Indriasari, R. Pola Konsumsi 
Terhadap Kejadian Obesitas Sentral pada Pegawai Pemerintahan di Kantor Bupati Kabupaten Jeneponto. Artikel Penelitian. Program Studi Ilmu Gizi Fakultas Kesehatan Masyarakat Universitas Hasanudin Makasar. 2013; $1-14$.

[BPS] Badan Pusat Statistik. Cianjur Da-lam Angka Tahun 2017. Kabupaten Cianjur: BPS Balitbangkes. 2014. Survey Konsum-si Makanan Individu:Studi Diet Total (SDT) 2014. Kementerian Kesehatan RI; 2017

Farisa S. Hubungan Sikap, Pengetahuan, Ketersediaan, dan Keterpaparan Media Massa dengan Konsumsi Buah dan Sayur pada Siswa SMPN 8 Depok. [Skripsi]. Depok: Program Studi Gizi Fakultas Kesehatan Masyarakat Universitas Indonesia; 2012.

Farisa. Hubungan Sikap, Pengetahuan, Ketersediaan dan Keterpaparan Media Massa den-gan Konsumsi Buah dan Sayur Pada Siswa SMPN 8 Depok Tahun 2012 [Skripsi]. Jakarta: Universitas Indonesia; 2012

Hermina, Prihatini S. Gambaran Konsum-si Sayur dan Buah Penduduk Indonesia dalam Konteks Gizi Seimbang: Analisis Lanjut Survei Konsumsi Makanan Individu (SKMI) 2014. Buletin Penelitian Kesehatan. 2016; 44(3):205-218

Karyawati, S. G. (2016). Hubungan Antara Konsumsi Sayur Dan Buah Dengan Kejadian Obesitas Pada Remaja Di Sma Muhammadiyah 3 Yogyakarta (Doctoral Dissertation, Universitas Alma Ata Yogyakarta).

Kementerian Kesehatan RI, Pedoman Gizi Seimbang. Jakarta : Kementerian Kesehatan RI; 2014.

Lestari AD. Faktor-faktor yang Behubungan dengan Perilaku Konsumsi Buah dan Sayur pada Siswa SMP Negei 226 Jakarta Selatan. [Skripsi].Jakarta: Program Studi Kesehatan Masyarakat Fakultas Kedokteran dan Ilmu Kesehatan Universitas IslamNegeri Syarif Hidayatullah; 2012.
Mourbas. Kebutuhan Gizi Remaja. Media Informasi Gizi dan Kesehatan Depkes RI. Padang: Padang; 2001.

Nurlidyawati. Faktor-faktor yang Berhubungan dengan Perilaku Konsumsi Buah dan Sayur pada Siswa Kelas VIII dan IX SMP Negeri 127 Jakarta Barat Tahun 2015. [Skripsi].Jakarta: Program Studi Kesehatan Masyarakat Fakultas Kedokteran dan Ilmu Kesehatan Universitas Islam Negeri Syarif Hidayatullah; 2015.

Riset Kesehatan Dasar (Riskesdas). 2018. RISKESDAS. Jakarta: Balitbang Kemenkes RI

Svastisalee, C., Holstein, B. \& Due, P. Fruit and Vegetable Intake in Adolescents: Associa-tion with Socioeconomic Status and Exposure to Supermarkets and Fast Food Outlet. J Nutr Metab. 2012;19.18 .

Suryani, N., Noviana, N., \& Libri, O. (2020). Hubungan Status Gizi, Aktivitas Fisik, Konsumsi Buah Dan Sayur Dengan Kejadian Hipertensi Di Poliklinik Penyakit Dalam RSD Idaman Kota Banjarbaru. Jurnal Kesehatan Indonesia, 10(2), 100107.

World Health Organization. (2005). WHO discussion papers on adolescence. Nutrition in adolescence-issues and challenges for the health sector. Geneva: WHO. 